\title{
Efforts to improve activities and results of student learning in civic education learning through Cooperative Learning model of Jigsaw type
}

\section{Upaya meningkatkan kegiatan dan hasil belajar siswa dalam pembelajaran pendidikan kewarganegaraan melalui model Pembelajaran Kooperatif tipe Jigsaw}

\author{
Yuli Zarnita ${ }^{1}$, Azwar Ananda ${ }^{2}$, Khairani ${ }^{3}$ \\ ${ }^{1}$ Social Education Program, Universitas Negeri Padang \\ ${ }^{23}$ Universitas Negeri Padang
}

\begin{abstract}
This research is motivated by the low activity and student learning outcomes in Civic Education subjects in class 11th social program 2 at Islamic Senior High School Number 2 Bukittinggi. The factors that cause low activity and student learning outcomes such as the lack of opportunities for students to explore potential, low motivation, learning models that are not varied. The purpose of this study was to obtain information on the increase in activity and student learning outcomes through the jigsaw type learning cooperative learning model in class 11th social program 2 at Islamic Senior High School Number 2 Bukittinggi. The type of this research is Classroom Action Research (CAR). The subject of the research was 25 people consisting of 18 female students and 7 male students. Based on the results of the study showed that there was an increase in activity in the first cycle of reading $60 \%$, discussing $64 \%$, listening to $64 \%$, presenting $49.3 \%$, asking $60 \%$, making a summary of $26.67 \%$, working on the test $42.67 \%$. In cycle II I read $86.3 \%$, discussed $86 \%$, listened to $86 \%$, presented 75.67 , asked 83.67 , made a summary of $68.33 \%$ and worked on the test $80 \%$. From the results of the study it can be concluded that Civics learning using the jigsaw type learning cooperative learning model can improve learning activities and student learning outcomes in class 11th social program 2 at Islamic Senior High School Number 2 Bukittinggi.
\end{abstract}

Keywords: Learning activities, learning outcomes, jigsaw, civic education

(i) This is an open access article distributed under the Creative Commons Attribution License, which permits unrestricted use, distribution, and reproduction in any medium, provided the original work is properly cited. (C2019 by author

\section{PENDAHULUAN}

Pemerintah setiap periode melalui kementerian pendidikan dan kebudayaan telah berupaya untuk memperbaiki mutu pendidikan melalui pergantian kurikulum dengan harapan dapat memperbaiki mutu lulusan.Terbukti dengan keluarnya kurikulum 2013 sebagai pengganti kurikulum KTSP 2006 dengan beberapa perbaikan dalam penilaian.Selain itu pemerintah juga telah membuat Badan Nasional Standar Pendidikan sebagai lembaga untuk memantau standar penilaian mata pelajaran di satuan pendidikan di Indonesia.Selain itu dengan adanya UU No. 20 tahun 2003 sebagai payung hukum sistem pendidikan nasional telah mencantumkan berbagai ketentuan untuk perbaikan pendidikan Indonesia.Dalam UU Sisdiknas dicantumkan juga tujuan mata pelajaran Pendidikan Kewarganegaraan (PKn) sebagai salah satu mata pelajaran wajib dalam setiap jenjang pendidikan di Indonesia. 
Pendidikan Kewarganegaraan adalah mata pelajaran yang bertujuan untuk membentuk manusia Indonesia seutuhnya yang berlandaskan pada Pancasila, Undang- Undang Dasar, dan norma yang berlaku di masyarakat. Selain itu PKn juga bertujuan untuk mengembangkan siswa menjadi warga negara yang cerdas dan baik.menurut Departemen Pendidikan Nasional, Pendidikan Kewarganegaraan (PKn) adalah salah satu mata pelajaran sebagai muatan wajib dalam kurikulum pendidikan dasar dan menengah (Pasal 37 ayat 1 UU Sistem Pendidikan Nasional).

Semenjak hilangnya mata pelajaran Pendidikan Moral Pancasila dan berganti menjadi Pendidikan Pancasila dan Kewarganegaraan banyak perubahan dalam teori dan aplikasinya. Muatan materi mata pelajaran PKn sangat berbeda dengan PMP, seperti kehidupan politik, hukum, pemerintahan, dan lembaga negara. Selain beratnya muatan isi mata pelajaran juga terbiasanya siswa sebagai pendengar dan pasif menerima semua penjelasan guru, sehingga terbentuklah siswa yang hanya menerima tanpa umpan balik. Rendahnya hasil belajar siswa tampak pada latihan harian, ulangan harian dan ujian mid semester. Pada ujian Mid semester yang berlangsung Maret 2016, hasil ujian siswa yang mencapai KKM 75 hanya 4 orang dari 25 siswa.Selain nilai tengah semester diatas, aktivitas siswa di kelas juga masih rendah seperti mengantuk, kurang gairah belajar, bersikap pasif, tidak banyak siswa yang bertanya atau mengeluarkan pendapat. Saat pemberian Pekerjaan Rumah (PR) masih banyak siswa yang tidak mengerjakan, mencontek PR teman dan tidak serius membuat tugas.

Oleh karena itu penulis mencari solusi dengan jalan menerapkan pembelajaran model kooperatif tipe Jigsaw dalam mata pelajaran PPKn di kelas XI.IPS 2.Model pembelajaran kooperatif dianggap tepat dalam pembelajaran PPKn karena memungkinkan siswa saling bekerjasama dan dapat melibatkan semua siswa secara aktif dalam memecahkan masalah belajar. Hal ini sesuai dengan pendapat David W. Johnson,dkk (2010:4-5), bahwa kooperatif learning merupakan proses belajar mengajar yang melibatkan penggunaan kelompok kecil yang memungkinkan siswa saling bekerjasama untuk memaksimalkan pembelajaran satu sama lainnya. Model pembelajaran kooperatif Selain itu dalam pembelajaran kooperatif ada interdependensi atau saling ketergantungan untuk mencapai tujuan siswa. Pembelajaran koopertaif ini memiliki banyak tipe, salah satunya yaitu Jigsaw.

Kooperatif learning tipe Jigsaw menurut Johnson (1991: 27) adalah kegiatan belajar secara kelompok kecil, siswa belajar dan bekerja sama sampai kepada pengalaman belajar yang maksimal, baik pengalaman individu maupun pengalaman kelompok. Dalam teknik ini guru dapat memperhatikan skemata atau latar belakang pengalaman siswa dan membantu siswa mengaktifkan skemata ini agar bahan pelajaran menjadi bermakna.Selain itu siswa mampu bekerjasama dalam suasana gotong royong dan mempunyai banyak kesempatan untuk mengolah informasi dan meningkatkan keterampilan berkomunikasi. Kooperatif tipe jigsaw dalam pelaksanaannya guru dapat mengelompokan siswa dalam kelompok yang heterogen, sehingga siswa akan lebih saling mengenal dan dapat saling membantu.

Jika dihubungkan dengan kondisi siswa di kelas XI.IPS 2 MAN 2 Kota Bukittinggi dapat diambil kesimpulan sementara bahwa hasil belajar siswa yang rendah karena kualitas pengajaran yang kurang optimal dan penggunaan metode diskusi kelompok yang kurang terarah. Selain itu masih mendominasinya guru dalam proses belajar sehingga siswa kurang mampu untuk mandiri membangun konsep. Pembelajaran kooperatif tipe Jigsaw dapat menyelesaikan permasalahan tersebut, karena dengan metode ini siswa dapat bekerjasama dalam kelompok kecil dan dapat saling membantu dalam belajar. Selain membantu siswa dalam memahami konsep yang sulit dalam PKN, kooperatif learning juga dapat menumbuhkan kemampuan kerjasama, berpikir kritis dan kemampuan memahami teman (Ibrahim dalam Jamil S, 2013: 192).

Pembelajaran kooperatif tipe Jigsaw diterapkan dengan mengintegrasikan berbagai macam aktivitas belajar kedalam aktivitas belajar yang sesuai dengan langkah jigsaw. Siswa dikelompokan kedalam kelompok ahli dan kelompok jigsaw sehingga setiap siswa memilikisaling ketergantungan positif. Setelah siswa membahas dalam kelompok ahli kemudian ssiwa bergabung ke dalam kelompok asal (jigsaw) yang terdiri dari berbagai macam materi pembahasan. Setiap siswa harus mampu mempresentasikan materi yang sudah menajdi tanggungjawabnya. Penggunaan model pembelajaran kooperatif learning tipe jigsaw ini diharapkan dapat meningkatkan aktivitas dan hasil belajar siswa dalam mata pelajaran PKn. Adapun rumusan masalah dalam penelitian ini adalah Bagaimana penggunaaan model pembelajaran kooperatif tipe Jigsaw dapat meningkatkan aktivitas belajar dan hasil belajar siswadalam mata pelajaran PKn di kelas XI.IPS 2 pada MAN 2 Kota Bukittinggi?

\section{METODE}

Penelitian ini menggunakan metode Penelitan Tindakan Kelas (PTK). PTK ini dilaksanakan selama dua siklus dan setiap siklus terdiri dari 3 kali pertemuan tatap muka ditambah dengan 1 kali ujian blok. Penelitian ini dilaksanakan di kelas XI.IPS 2 MAN 2 Bukittiggi. Adapun subjek dalam penelitian ini adalah 25 siswa yang terdiri dari 17 siswa perempuan dan 8 orang siswa laki-laki. Setiap siklus dalam PTK terdiri dari tahap 
perencanaan, tindakan, obsevrasi, dan refleksi. Adapun langkah- langkah yang peneliti lakukan dalam setiap siklus adalah:

\section{Tahap Perencanaan}

Adapun langkah- langkah yang dilakukan dalam tahap ini yaitu : 1) Menyiapkan proposal penelitian; 2) Melakukan observasi awal di lokasi penelitian; 3) Mempersiapkan silabus dan Rencana Pelaksanaan Pembelajaran (RPP); 4) Menyiapkan lembar observasi dan lembar penilaian siswa; 5) Mengkonsultasikan proposal kepada pembimbing; 6) Menetapkan jadwal penelitian; 7) Menyusun soal untuk ujian blok 1 dan 2.

\section{Tahap Tindakan (action)}

Dalam kegiatan ini peneliti sebagai guru pelaksana dan dibantu 2 orang guru bidang studi lainnya sebagai observer. Sebelum melakukan tahap ini penulis mendiskusikan terlebih dahulu mengenai hal- hal yang harus diperhatikan para observer selama proses pembelajaran berlangsung, serta hal- hal yang harus dilakukan siswa.

\section{Tahap observasi (observation)}

Pada tahap pengamatan ini guru bersama observer mengamati semua peristiwa yang terjadi dalam proses pembelajaran yang dicatat dalam catatan lapangan serta lembaran observasi .segala hal permasalahan yang menghambat aktivitas belajar, hasil belajar dan motivasi siswa dicatat. Dalam kegiatan pengamatan ini peneliti dibantu sejawat sebanyak 2 orang guru. Adapun hal- hal yang harus diamati pada kegiatan ini adalah : 1) Siswa mampu menjelaskan keterkaitan materi dengan kehidupan sehari- hari seperti permasalahan status kewarganegaraan seseorang yang sering dilihat di media massa; 2) Siswa mampu bekerjasama dalam kelompok ahli dan mampu menjelaskan kembali di kelompok asalnya; 3) Siswa mampu untuk bertanya, memberikan saran dan memberikan jawaban serta tanggapan; 4) Siswa mampu untuk mempresentasikan hasil pembahasan dalam kelompok; 5) Siswa dapat membuat refleksi dari hasil diskusinya; 6) Siswa mampu mengerjakan soal yang diberikan guru di akhir pembelajaran.

\section{Tahap Refleksi(reflection)}

Dalam PTK ini kegiatan refleksi dapat tergambar hasil yang telah tercapai setelah kegiatan tindakan dan pengamatan dilakukan pada Siklus I. Maka observer bersama guru mendiskusikan tentang peristiwa yang terjadi selama pembelajaran seperti berikut ini: 1) Permasalahan yang terjadi selama pembelajaran; 2) Kekurangan yang dilakukan guru selama proses pembelajaran; 3) Interkasi antar siswa dan asktivitas siswa selama pembelajaran; 4) Siswa yang masih bermotivasi rendah.

\section{HASIL PENELITIAN}

\section{Siklus I}

Observasi dilakukan pada semua kegiatan atau aktivitas belajar siswa dalam setiap pertemuan. Pertemuan pada siklus 1 dalam proses belajar mengajar sebnayak 3 kali ditambah dengan 1 kali ujian blok. Pertemuan pertama yaitu membahas tentang sengketa internasional beserta penyebab dan cara penyelesaiannya, materi pertemuan kedua yaitu peranan Mahkamah Internasional, dan pertemuan ketiga yaitu prosedur penyelesaian sengketa internasional. Prosedur pembelajaran dalam setiap pertemuan disesuaikan dengan tahapan yang ada dalam RPP yang terintegrasi dengan macam- macam aktivitas dalam tipe jigsaw.

Jumlah aktivitas belajar siswa yang diamati terdiri dari delapan indikator yaitu membaca materi yang diberikan guru dalam kelompok asal, mendiskusikan pokok bahasan yang sama dalam tim ahli, mendengarkan penjelasan teman dalam kelompok asal/ mengajarkan teman dalam kelompok asal tentang pokok bahasan yang telah dibahas dari kelompok ahli, mempresentasikan hasil diskusi dihadapan kelompok jigsaw, mengajukan pertanyaan, membuat rangkuman dan mengerjakan tes. Adapun hasil pengamatan aktivitas belajar siswa dalam siklus 1 dapat dilihat pada tabel berikut ini : 
Tabel 1 Aktivitas Belajar Siswa Kelas XI. IPS 2 pada Siklus I

\begin{tabular}{|c|c|c|c|c|c|c|c|c|}
\hline \multirow{3}{*}{$\begin{array}{c}\text { Jenis } \\
\text { Aktivitas } \\
\text { siswa }\end{array}$} & \multicolumn{6}{|c|}{ Hasil Pegamatan pada pertemuan ke } & \multirow[t]{3}{*}{ Rata- rata } & \multirow[t]{3}{*}{ Kategori } \\
\hline & \multicolumn{2}{|r|}{1} & \multicolumn{2}{|c|}{2} & \multicolumn{2}{|c|}{3} & & \\
\hline & $\mathrm{f}$ & PK & $\mathrm{f}$ & PK & $\mathrm{F}$ & PK & & \\
\hline $\mathbf{A}$ & 12 & 48 & 15 & 60 & 18 & 72 & 60 & Baik \\
\hline $\mathbf{B}$ & 16 & 60 & 15 & 60 & 18 & 72 & 64 & Baik \\
\hline $\mathbf{C}$ & 13 & 52 & 16 & 64 & 19 & 76 & 64 & Baik \\
\hline D & 4 & 16 & 16 & 64 & 17 & 68 & 49,3 & Baik \\
\hline $\mathbf{E}$ & 9 & 36 & 17 & 68 & 19 & 76 & 60 & Baik \\
\hline $\mathbf{F}$ & 2 & 8 & 7 & 28 & 11 & 44 & 26,67 & Cukup \\
\hline $\mathbf{G}$ & 6 & 24 & 12 & 44 & 14 & 56 & 42,67 & Cukup \\
\hline
\end{tabular}

Keterangan :

A : membaca materi yang diberikan guru dalam kelompok asal

B : mendiskusikan pokok bahasan yang sama dalam tim ahli

C : mendengarkan penjelasan teman dalam kelompok asal/ mengajarkan teman dalam kelompok asal tentang pokok bahasan yang telah dibahas dari kelompok ahli

D : mempresentasikan hasil diskusi dalam kelompok jigsaw

E : mengajukan pertanyaan

F : membuat rangkuman (kegiatan menulis)

G : siswa mengerjakan tes

$F \quad=$ Jumlah siswa yang melakukan aktivitas dalam belajar

$P K=$ Presentase Klasikal (\%)

Berdasarkan tabel 1 diatas dapat dilihat bahwa aktivitas belajar siswa dari pertemuan 1 sampai pertemuan ketiga sudah mengalami peningkatan. Namun pada aktivitas berdiskusi dalam tim ahli pada pertemuan kedua mengalami penurunan karena materi pada pertemuan kedua cukup sulit bagi siswa karena ada membahas tentang mekanisme penyelesaian sengketa internasional dalam Mahkamah Internasional. Sedangkan pada indikator mempresentasikan hasil diskusi dalam kelompok jigsaw sangat mengalami peningkatan terutama dari pertemuan satu ke pertemuan dua hal ini karena guru sudah memberikan kritikan dan saran kepada kelompok yang masih pasif pada akhir pertemuan satu sehingga pada pertemuan kedua siswa menjadi lebih semangat. Pada indikator lain rata- rata juga mengalami peningkatan seiring dengan motivasi dan reward yang diberikan guru kepada kelompok yang aktif. Agar lebih mudah melihat peningkatan aktivitas belajar siswa dari berbagai indikator berikut disajikan dalam bentuk diagram batang :

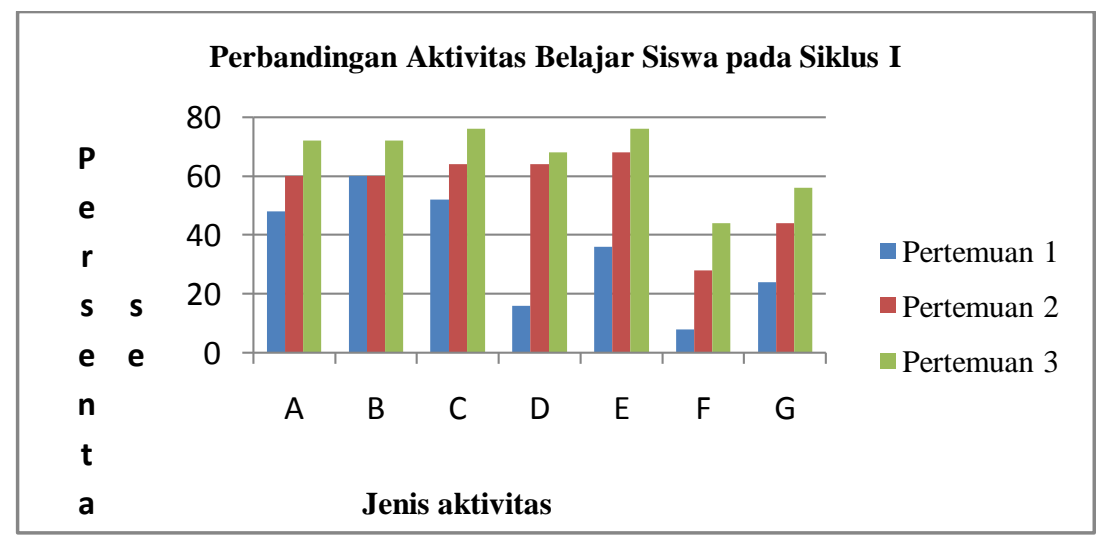

Gambar 1. Diagram batang aktivitas belajar siswa pada siklus 1

Untuk melihat tingkat kognitif siswa dalam belajar, maka penulis mengadakan Evaluasi hasil belajar dengan posttes dan ujian blok 1 pada akhir siklus 1 . Pada posttest diberikan pada setiap akhir pertemuan proses pembelajaran. Pada siklus I peneliti melakukan 3 kali postest,adapun hasil dari postest dapat dilihat pada tabel berikut ini : 
Tabel 2 : Rata- rata posttest siswa pada siklus 1

\begin{tabular}{ccccc}
\hline Siklus I & Pertemuan 1 & Pertemuan 2 & Pertemuan 3 & Ujian Blok 1 \\
\cline { 2 - 5 } & Rata- rata nilai & Rata- rata nilai & Rata- rata nilai & Rata- rata nilai \\
& 63 & 74 & 83 & 62,52 \\
\hline
\end{tabular}

Berdasarkan tabel diatas dapat kita lihat pada awal pertemuan terdapat rata- rata klasikal 63, sedangkan pada pertemuan kedua mengalami peningkatan yaitu 74 dan pertemuan ketiga menjadi 83. Pada siklus satu dapat kita lihat bahwa dalam pertemuan satu dan dua rata- rata klasikal belum mencapai KKM kelas yaitu 75. Akan tetapi peningkatan dapat kita lihat pada pertemuan ketiga yaitu rata- rata klasikal menjadi 83. Rendahnya pencapaian rata- rata klasikal pada pertemuan satu dan dua, karena siswa belum terbiasa dengan postest selesai proses belajar mengajar yang berpusat pada siswa, ditambah lagi dengan keterbatasan waktu, sehingga banyak yang menjawab pertanyaan soal dengan apa adanya. Pada pertemuan ketiga mengalami peningkatan karena sudah mulai terbiasa dengan posttes dan adanya kompetisi antar kelompok.

Selain hasil postes juga diperoleh hasil ujian blok atau UH pada siklus I jumlah siswa yang tuntas yaitu 13 orang. Dalam hal ini diperoleh nilai rata- rata klasikal 62,52\%. Target ketuntasan belajar baru mencapai $48 \%$ dari jumlah siswa yang ada yaitu 25 orang. Artinya hasil belajar belum mencapai target, oleh karena itu penelitian ini harus dilanjutkan pada siklus II.

Catatan lapangan pada siklus I masih banyak siswa yang malu- malu untuk bertanya, kebanyakan dari siswa membacakan hasil diskusi dari kelompok ahli bukannya membahas dan menjelaskan lebih detil. Sehingga siswa yang slow repond masih susah memahami. Kendala terbesar terletak pada aktivitas membuat kesimpulan karena siswa selama ini belum terbiasa mandiri menuliskan kesimpulan dan refleksi. Selain itu saat mengerjakan postes masih ada siswa yang mencontek dan asal- asalan, karena keterbatasan waktu serta kurang fokus mendengarkan presentasi siswa lainnya dalam kelompok asal. Dari berbagai pemaparan diatas dapat disimpulkan beberapa kendala yang dialami pada siklus I yaitu : 1) Siswa yang kategori pintar lebih banyak menggunakan waktu dalam mempresentasikan materinya sehingga siswa pada materi terakhir tidak maksimal; 2) Waktu kegiatan inti masih kurang karena belum terbiasanya siswa dengan pembelajaran tipe jigsaw serta kegiatan siswa pindah dari tim ahli ke tim jigsaw juga memakan waktu; 3) Masih banyak siswa yang belum berani bertanya serta menanggapi penjelasan siswa lainnya; 4) Saat siswa lain mempresentasikan materinya masih ada siswa yang kurang memperhatikan dan kadang mengajak anggota lainnya membicarakan hal diluar pelajaran; 5) Masih banyak siswa yang tidak mampu membuat kesimpulan dalam catatan

Berdasarkan hasil observasi diketahui beberapa indikator mengalami kenaikan seperti membaca, mendengarkan, mempresentasikan, mengajukan pertanyaan, membuat rangkuman dan mengerjakan kuis. Walaupun begitu belum semua siswa terlibat aktif dalam proses belajar dalam setiap pertemuannya. Oleh sebab itu guru harus membuat perencanaan perbaikan pada siklus berikutnya. Adapun langkah- langkah perbaikan yang dilakukan guru agar semua siswa terlibat aktif dan hasil belajar siswa mencapai ketuntasan adalah sebagai berikut : 1) Saat membahas materi dalam kelompok ahli, guru harus berkeliling dan observer harus memperhatikan siswa yang aktif dan pasif dalam berdiskusi dalam kelompok ahli; 2) Untuk mengatasi kekurangan waktu, guru harus mengatur posisi letak kelompok agar siswa tidak saling berdebat menentukan lokasi tempat duduk kelompoknya; 3) Guru harus memperhatikan satu persatu dengan berkeliling dari kelmpok ke kelompok untuk memastikan siswa tidak hanya sebagai pendengar tetapi mampu mengajukan pertanyaan tanpa malu- malu; 4) Guru harus menekankan kepada siswa sukses kelompok jigsaw tergantung cara siswa belajar dalam tim ahli, sehingga setiap siswa merasa bertanggungjawab terhadap materi yang dimilikinya; 5) Guru mengumumkan kelompok yang paling aktif dalam setiap pertemuan dan mengumumkan rata- rata capaian kelompok dalam setiap pertemuannya; 6) Agar siswa tidak asal- asalan dalam mengerjakan kuis, guru menyampaikan bahwa selain nilai capaian individu mempengaruhi keberhasilan kelompok, jika ada satu siswa dalam tim tidak serius maka nilai tim akan jatuh.

\section{Siklus II}

Jenis aktivitas belajar siswa pada siklus II yang diamati masih sama dengan kegiatan pada siklus I yaitu membaca materi yang diberikan guru dalam kelompok asal, mendiskusikan pokok bahasan yang sama dalam tim ahli , mendengarkan penjelasan teman dalam kelompok asal/ mengajarkan teman dalam kelompok asal tentang pokok bahasan yang telah dibahas dari kelompok ahli , mempresentasikan hasil diskusi dalam kelompok jigsaw, mengajukan pertanyaan, membuat rangkuman (kegiatan menulis) dan siswa mengerjakan tes. Hasil observasi aktivitas belajar siswa pada siklus II dapat dilihat pada tabel berikut ini : 
Tabel 3. Aktivitas belajar siswa kelas XI.IPS 2 Siklus II

\begin{tabular}{|c|c|c|c|c|c|c|c|c|}
\hline \multirow[t]{3}{*}{ Jenis Aktivitas siswa } & \multicolumn{6}{|c|}{ Hasil Pegamatan pada pertemuan ke } & \multirow[t]{3}{*}{ Rata- rata } & \multirow[t]{3}{*}{ Kategori } \\
\hline & \multicolumn{2}{|c|}{5} & \multicolumn{2}{|c|}{6} & \multicolumn{2}{|c|}{7} & & \\
\hline & $\mathrm{f}$ & PK & $\mathrm{F}$ & PK & $\mathrm{f}$ & PK & & \\
\hline $\mathbf{A}$ & 17 & 85 & 20 & 86 & 22 & 88 & 86,3 & Sangat Baik \\
\hline $\mathbf{B}$ & 16 & 80 & 20 & 86 & 23 & 92 & 86 & Sangat Baik \\
\hline $\mathbf{C}$ & 16 & 80 & 19 & 82 & 24 & 96 & 86 & Sangat Baik \\
\hline D & 14 & 70 & 17 & 73 & 21 & 84 & 75,67 & Sangat Baik \\
\hline $\mathbf{E}$ & 17 & 85 & 18 & 78 & 22 & 88 & 83,67 & Sangat Baik \\
\hline $\mathbf{F}$ & 11 & 55 & 17 & 74 & 19 & 76 & 68,33 & Baik \\
\hline $\mathbf{G}$ & 14 & 70 & 19 & 82 & 22 & 88 & 80 & Sangat Baik \\
\hline
\end{tabular}

Keterangan :

A : membaca materi yang diberikan guru dalam kelompok asal

B : mendiskusikan pokok bahasan yang sama dalam tim ahli

C : mendengarkan penjelasan teman dalam kelompok asal/ mengajarkan teman dalam kelompok asal tentang pokok bahasan yang telah dibahas dari kelompok ahli

D : mempresentasikan hasil diskusi dihadapan kelompok jigsaw

E : mengajukan pertanyaan

F : membuat rangkuman (kegiatan menulis)

G : siswa mengerjakan tes

$F \quad=$ Jumlah siswa yang melakukan aktivitas dalam belajar

$P K=$ Presentase Klasikal $(\%)$

Berdasarkan tabel 3 diatas dapat kita lihat peningkatan setiap indikator dari pertemuan 5, 6 dan 7 pada siklus II. Agar lebih mudah memahami peningkatan aktivitas belajar siswa disajikan dalam bentuk diagram batang pada gambar berikut ini :

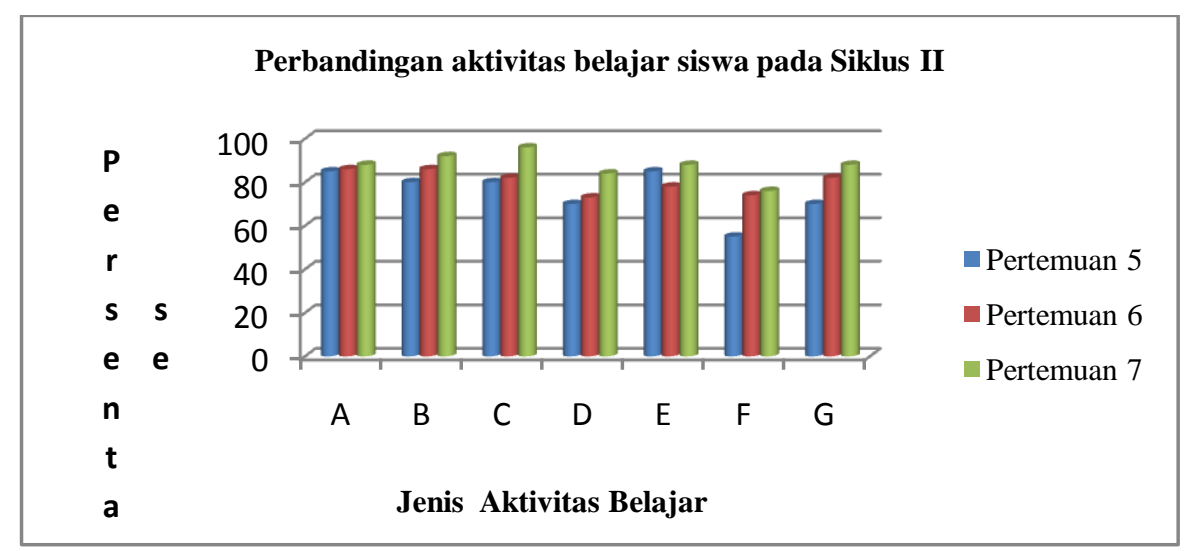

Gambar 2. Diagram batang aktivitas belajar siswa pada siklus II

Berdasarkan tabel 3 dan gambar 2 diatas dapat kita lihat peningkatan berbagai jenis aktivitas belajar dan masih ada satu aktivitas belajar menagalami penurunan. Penurunan indikator ini karena ada 2 orang siswa yag tidak hadir, dari 23 siswa yang hadir yang banyak memberikan pertanyaan sesuai dengan materi yang dibahas yaitu 18 orang siswa. Selain itu materi pada pertemuan keeenam ini dirasa sangat mudah bagi siswa karena sebagian besar sudah menguasai materi ini. Pada siklus II ini materi pelajaran yang dibahas yaitu mengenai materi yang beum tuntas pada siklus I, semua siswa sudah mempelajari ini sebelumnya akan tetapi guru lebih mempertajam pada materi yang belum dikuasai siswa. Rata- rata aktivitas belajar mengalami kenaikan persentase seperti mendengarkan penjelasan teman pada saat presentasi dalam kelompok jigsaw serta membuat kesimpulan. Pada pertemuan dalam siklus II sangat mengalami kenaikan dalam peretmuan kelima sebanyak 14 siswa, pertemuan keenam 19 dan pertemuan ketujuh menjadi 22 siswa. Kenaikan ini disebabkan oleh guru dan observer benar- benar memperhatikan satu persatu catatan siswa dan berkeliling dari satu kelompok ke kelmpok lain sehingga tidak ada yang luput dari pengamatan. Selain itu guru juga menekankan kepada semua siswa harus membuat kesimpulan tiap materi dari teman yang berbeda materi. 
1. Pertemuan ke lima (siklus 2 pertemuan 1)

Pertemuan kelima ini dilaksanakan pada hari Selasa tanggal 24 Mei 2016 yang dihadiri 20 orang siswa, sebanyak 5 orang siswa tidak hadir karena 2 orang sakit dan 3 orang mengikuti lomba. Pada pertemuan kelima atau pertemuan satu dalam siklus II ini ada beberapa hal yang diganti seperti susunan anggota kelompok ahli dan kelompok asal. Peneliti masih membagi siswa dalam 5 kelompok ahli (lampiran 24) dan 5 kelompok asal (lampiran 25) karena ada 5 siswa yang tidak hadir, maka anggota setiap kelompok menjadi 4 orang.

2. Pertemuan ke enam (siklus 2 pertemuan 2)

Pertemuan keenam atau kedua jika dalam siklus II, peneliti melaksakannya pada hari Rabu tanggal 25 Mei 2016. Hal ini dikarenakan jam pelajaran PPKn hanya 1 kli seminggu, sehingga untuk melakukan penelitian ini peneliti meminta jam guru Bahasa Inggris agar bisa melaksanakan penelitian ini. Pertukaran jam ini sudah dibicarakan dengan siswa yang juga diumumkan pada pertemuan sebelumnya agar semua siswa tetap membawa buku PPKn pada hari yang telah disepakati.

3. Pertemuan ke tujuh (siklus 2 pertemuan 3 )

Pertemuan ketiga dalam sikulus 2 ini diadakan pada hari Kamis tanggal 26 Mei 2016, adapun pada pertemuan tersebut dihadiri oleh semua siswa yang berjumlah 25 orang. Pada pertemuan ini materi pelajaran yang akan dibahas adalah mengenai prosedur penyelesaian sengketa internasional melalui Mahkamah Internasional. Dalam pelaksanaan pembelajaran ini siswa masih dikelompokan dalam kelompok yang sama baik dalam kelompok ahli maupun dalam kelompok asalnya. Untuk keberhasilan penelitian ini peneliti amsih dibantu 2 orang observer. Alur pelaksanaan pembelajran ini disesuaikan dengan RPP-7 yang terlampir dalam Lampiran -3.

4. Pertemuan ke delapan (siklus 2 pertemuan 4)

Pertemuan kedelapan atau pertemuan keempat dalam Siklus II yaitu untuk pelaksanaan ujian blok II. Adapun ujian ini dilaksanakan pada hari Kamis tanggal 2 Juni 2016. Ujian ini dihadiri oleh semua siswa yaitu sebanyak 25 orang. Pada pertemuan ini masing- masing siswa mengerjakan dua jenis soal yaitu 15 soal objektif dan 4 soal essay (Lampiran-8) selama 45 menit.

\section{Pengamatan tindakan (observasi)}

\section{Pengumpulan data}

Observasi mengenai aktivitas belajar siswa selama mengikuti pembelajaran 3 kali pertemuan dengan model pembelajaran kooperatif learning tipe jigsaw pada siklus II dapat dilihat pada tabel 17 berikut ini :

Tabel 17. Aktivitas belajar siswa pada siklus II menggunakan model kooperatif learning tipe jigsaw

\begin{tabular}{|c|c|c|c|c|c|c|c|}
\hline \multirow[t]{3}{*}{ Jenis Aktivitas siswa } & \multicolumn{6}{|c|}{ Hasil Pegamatan pada pertemuan ke } & \multirow[t]{3}{*}{ Kategori } \\
\hline & \multicolumn{2}{|c|}{5} & \multicolumn{2}{|c|}{6} & \multicolumn{2}{|c|}{7} & \\
\hline & $\mathrm{f}$ & PK & $\mathrm{F}$ & PK & $\mathrm{f}$ & PK & \\
\hline $\mathbf{A}$ & 17 & 85 & 20 & 86 & 22 & 88 & Sangat Baik \\
\hline B & 16 & 80 & 20 & 86 & 23 & 92 & Sangat Baik \\
\hline $\mathbf{C}$ & 16 & 80 & 19 & 82 & 24 & 96 & Sangat Baik \\
\hline D & 14 & 70 & 17 & 73 & 21 & 84 & Sangat Baik \\
\hline $\mathbf{E}$ & 17 & 85 & 18 & 78 & 22 & 88 & Sangat Baik \\
\hline $\mathbf{F}$ & 11 & 55 & 17 & 74 & 19 & 76 & Baik \\
\hline $\mathbf{G}$ & 14 & 70 & 19 & 82 & 22 & 88 & Sangat Baik \\
\hline
\end{tabular}

Pada siklus II ini evaluasi setiap akhir belajar dilakukan sebanyak 3 kali yaitu pada pertemuan 5, 6 dan 7 (lampiran 19). Untuk lebih jelasnya kita dapat melihat tingkat rata- rata klasikal setiap pertemuan pada tabel 18 sebagai berikut :

\begin{tabular}{cccc}
\hline Siklus II & Pertemuan 5 & Pertemuan 6 & Pertemuan 7 \\
\cline { 2 - 4 } & Rata- rata nilai & Rata- rata nilai & Rata- rata nilai \\
& 85 & 87 & 89 \\
\hline
\end{tabular}


Selain dalam bentuk tabel, data hasil belajar siswa pada pertemuan 5, 6 dan 7 juga disajikan dalam bentuk diagram batang. Melalui diagram batang tersebut kita dapat melihat perbandingan dan peningkatan hasil belajar siswa pada setiap pertemuan dalam siklus II.

Berdasarkan tabel diatas dapat kita jelaskan bahwa sudah terjadi peningkatan apek kognitif siswa dari pertemuan kelima, keenam dan ketujuh. Pada pertemuan kelima kuis yang dikerjakan siswa setelah pembelajaran, secara klasikal memiliki rata- rata 85\%. Berdasarkan angka tersebut sudah memiliki kategori sangat baik dibanding siklus I, jika dilihat data pada lampiran 18 dapat kita kelompokan data ketuntasan siswa laki- laki dan perempuan, dari 20 siswa yang hadir pada pertemuan 5 ada 2 orang siswa laki- laki yang tidak tuntas yaitu FI dan AF. Sedangkan siswa perempuan yang tidak tuntas yaitu AN dan RR. Selain nilai postes pada siklus II juga diperoleh hasil tes pada ujian blok II. Adapun jumlah siswa yang tuntas yaitu sebanyak 20 orang siswa maka diperoleh nilai rata- rata klasikal 78\% dan ketuntasan sudah mencapai $80 \%$.

\section{Refleksi siklus II}

Setelah melakukan penelitian dalam 2 kali siklus, seperti pada siklus I peneliti juga melakukan refleksi dengan 2 orang observer yang telah membantu dalam menjalankan penelitian ini. Refleksi ini bertujuan agar peneliti merenungkan, dan memahami proses yang telah berjalan, masalah yang timbul, serta hambatan yang dilalui. Setelah menerapkan model pembelajaran kooperatif learning tipe jigsaw selama 2 siklus, dalam refleksi siklus II ini dapat kita lihat indikator- indikator yang telah berhasil baik dari aspek aktivitas belajar, hasil belajar maupun motivasi belajar siswa. Adapun hasil refleksi aktivitas belajar, hasil belajar dan motivasi belajar siswa dapat dilihat pada penjabaran berikut ini : 1) Aktivitas siswa yang meliputi tujuh indikator yaitu membaca, memecahkan masalah, mempresentasikan, bertanya, semangat dalam diskusi, membuat kesimpulan dan membuat ringkasan materi. Dari semua indikator tersebut dari setiap pertemuan dalam dua kali siklus sudah menunjukan peningkatan aktivitas belajar pada siswa kelas XI.IPS 2 dalam belajar PKn.

Akan tetapi dari tujuh indikator tersebut pada indikator nomor 6 yaitu membuat kesimpulan, siswa masih banyak yang belum mampu secara mandiri untuk membuat kesimpulan. Selain itu lamanya penelitian juga harus diatasi peneliti dengan berbagai teknik agar siswa tidak bosan dalam mengikuti pembelajaran, 2) Siswa yang biasanya pasif sekarang sudah banyak yang aktif dalam mengikuti pembelajaran. Setiap siswa sudah punya keberanian dalam mengungkapkan materi pelajaran, tampil ke depan kelas, serta mampu menanggapi pertanyaan dari siswa lainnya. Sehingga jika mengalami masalah belajar, mereka tidak selalu mengandalkan guru. Walaupun masih ada beberapa yang masih pasif, akan tetapi persentasenya tidak lebih dari 3\%, 3) Pada hasil belajar dapat kita lihat bahwa sudah terjadi peningkatan yang terjadi, yang sebelumnya banyak siswa mendapatkan nilai UH dibawah KKM, begitu juga dengan nilai MID semester 2 yang telah mereka dapatkan pada tahun ajaran 2015-2016. Banyak siswa yang mendapatkan nilai dibawah 75.

\section{PEMBAHASAN}

Dimyati dan Mudjiono (2002) mengemukakan bahwa terdapat beberapa prinsip belajar yang digunakan sebagai dasar dalam upaya pembelajaran yaitu perhatian dan motivasi, keaktifan, keterlibatan langsung/pengalaman, pengulangan, tantangan, balikan dan penguatan, serta perbedaan individual.Berdasarkan pendapat yang dikemukakan oleh Dimyati dan Mudjiono tersebut dapat diambil suatu kesimpulan bahwa salah satu prinsip belajar adalah keaktifan. Jadi keaktifan dalam proses pembelajaran sangat penting karena pada dasarnya belajar tersebut adalah perubahan tingkah laku. Hal ini sesuai dengan pendapat Gagne yang mengatakan bahwa belajar adalah suatu proses perubahan tingkah laku akibat suatu pengalaman. Jika siswa aktif dalam belajar maka siswa akan memperoleh banyak pengalaman. Apabila pengalaman yang dimiliki siswa juga banyak maka akan terjadi perubahan tingkah laku.

Rendahnya aktivitas siswa pada bertanya dalam kelompok berdasarkan siswa disebabkan dalamsiklus I ada tiga indikator dalam aktivitas siswa yang masih mendapatkan persentase rendah secara klasikal seperti mengajukan pertanyaan di kelompok asal. Siswa yang kurang serius saat di kelompok ahli tentunya akan berpengaruh saat berdiskusi di kelompok asal. Pada siklus I masih banyak yang belum berani bertanya, semua siswa sekedar menjelaskan materi pelajaran yang telah dibahas, akan tetapi tidak banyak yang saling bertanya.Permasalahn kedua yaitu siswa masih banyak yang belum memperhatikan penjelasan teman dalam kelompok asal serta belum banyak yang memperhatikan penjelasan guru.Dari temuan pada siklus ke dua yang berkaitan dengan aktivitas belajar siswa pada pembelajaran PKn setelah menggunakan model pembelajaran kooperatif tipe jigsaw yang terdiri dari tiga kali pertemuan juga sesuai dengan aspek yang di amati ternyata bahwa aktivitas dengan persentase yang tertinggi adalah pada mempresentasikan hasil diskusi kelompok ahli dalam kelompok asal (Jigsaw). 
Pada Temuan tersebut sesuai dan didukung oleh pendapat Sadirman (2009) pada bagian (oral aktivities) yaitu mengatakan, merumuskan, bertanya, memberi saran, mengeluarkan pendapat, mengadakan wawancara dan diskusi, selanjutnya pada bagian ( mental aktivities) yaitu menanggapi, mengingat, memecahkan soal, menganalisis, melihat hubungan dan mengambil keputusan. Serta pada bagian (emotional aktivities) yaitu menarik minat, merasa bosan, gembira, bersemangat, bergairah, berani, tenang dan gugup. Sesuai dengan kutipan di atas dapat di ketahui bahwa yang paling banyak melakukan aktivitas atau kegiatan dalam proses pembelajaran adalah anak atau siswa itu sendiri, sedangkan guru berperan sebagai fasilitator dan arahan serta merencanakan segala kegiatan yang akan di lakukan siswa dalam kegiatan pembelajaran.

\section{KESIMPULAN}

Sesuai dengan rumusan masalah dan tujuan penelitian yang telah dikemukakan, maka dapat disimpulkan berdasarkan temuan dah hasil penelitian yang telah diuraikan pada bab sebelumnya, dapat diambil kesimpulan bahwa aktivitas belajar dan hasil belajar siswa kelas XI.IPS 2 pada MAN 2 Kota Bukittinggi dengan menerapkan model pembelajarn kooperatif learning tipe jigsaw mengalami peningkatan mulai dari siklus I sampai dengan siklus II.

\section{REFERENCES}

Anita, Lie. (2003). Cooperative Learning: Mempraktekkan Cooperative Learning di Ruang- Ruang Kelas. Jakarta: Grasindo

Asep Jihad,dkk. (2012). Evaluasi Pembelajaran. Yogyakarta: Multi Pressindo

Darmansyah. (2009). PTK Pedoman Praktis Bagi Guru dan Dosen. Padang: Sukabina Press

Etin, Solihatin. (2012). Strategi Pembelajaran PKn. Jakarta: Bumi Aksara

Etin, Solihatin,dkk. Cooperatif Learning : Analisis Model Pembelajaran IPS. Jakarta: Bumi Aksara

Ghullam Hamdu, Lisa Agustina.Jurnal Penelitian Pendidikan Vol. 12 No. 1, April 2011 Pengaruh Motivasi Belajar Siswa Terhadap Pestasi Belajar Ipa Di Sekolah Dasar ((Studi Kasus terhadap Siswa Kelas IV SDN Tarumanagara Kecamatan Tawang Kota Tasikmalaya). http://jurnal.upi.edu/file/8Ghullam_Hamdu1.pdf

Hamzah.B.Uno. (2010). Profesi Kependidikan "Problema, Solusi dan Reformasi Pendidikan di Indonesia. Jakarta : Bumi Aksara

ilhamzen09. Uji t Dua Sampel.https://freelearningji.wordpress.comApril 6, 2013

Isjoni. (2009). Cooperative Learning: Efektifitas Pembelajaran Kelompok. Bandung: Alfabeta

Iskandar. (2009). Penelitian Tindakan Kelas.Jakarta: Gaung Persada Press

Iskandar, Agung. (2012). Strategi Penerapan PEndidikan Pembangunan Berkelanjutan (ESD) di Sekolah. Jakarta: Bee Media indonesia

Jamil , Suprihatiningrum. (2013). Strategi Pembelajaran: Teori dan Aplikasi,. Jogjakarta: Ar- Ruzz Media

Keke T. Aritonang. 11 Jurnal Pendidikan Penabur - No.10/Tahun ke-7/Juni 2008.Minat dan Motivasi dalam Meningkatkan Hasil Belajar Siswa.http://www.bpkpenabur.or.id/

Kunandar. (2008). Langkah Mudah Penelitian Tindakan Kelas Sebagai Pengembangan Profesi Guru.Jakarta : Rajawali Pers

Mujmal.I.W,dkk. (2013). e-Journal Program Pascasarjana Universitas Pendidikan Ganesha Program Studi Pendidikan Dasar (Volume 3 Tahun 2013). Pengaruh Pembelajaran Kooperatif Tipe Jigsaw Terhadap Motivasi Dan Hasil Belajar Ips Kelas Viii Mts Nw Gereneng Kecamatan Sakra Timur Ntb Tahun Pelajaran. 2011/2012. http://pasca.undiksha.ac.id/

Munandir. (2009). Kapita Selekta Pendidikan (Acuan Khusus: Pembelajaran dan Bimbingan)Jakarta: Pustaka Publisher

Nana, Sudjana. (2009). Penialian Hasil Proses Belajar Mengajar.Bandung : Remaja Rosdakarya

Nur, Asma. (2012). Model Pembelajaran Kooperatif. Padang: UNP Press. Padang: UNP Press

Ridwan,Abdullah Sani. (2014. Pembelajaran saintifik untuk Impelementasi Kurikulum 2013. Jakarta: Bumi Aksara

Rusman. (2011). Model- Model Pembelajaran: Pengembangan Profesonalisme Guru. Jakarta: Rajawali Pers

Sardiman. (2010). Interaksi dan Motivasi Belajar- Mengajar. Jakarta: Rajawali Pers

Sri, Untari. (2010). Model Pembelajaran Inovatif Berbasis Nilai Pancasila. Malang: UNM

S. Nasution. (2004). Didaktik Asas- Asas Mengajar. Jakarta: Bumi Aksara.

Syaiful, Bahri Djamarah,dkk. 2013. Strategi Belajar Mengajar. Jakarta : Rineka Cipta

Sofan,Amri. (2013). Pengembangan dan Model Pembelajaran dalam Kurikulum 2013. Jakarta: Prestasi Pustakaraya

Sugiyono . Metode Penelitian Pendidikan : Pendekatan Kuantitatif, Kualitatif dan R and D. Bandung: Alfabeta 
Sugiyono. (2000). Statistika Untuk Penelitian.Bandung:Alfabeta.

Suryosubroto. (2009). Proses Belajar mengajar di Sekolah "wawasan baru, beberapa metode pendukung, dan beberapa komponen layanan khusus. Jakarta : Rineka Cipta

Trianto. (2010). Model Pembelajaran Terpadu "Konsep, Strategi, dan Implementasinya dalam KTSP.Jakarta: Bumi Aksara

Wina Sanjaya. (2013). Perencanaan dan Desain Sistem Pembelajaran. Jakarta: Kencana Prenada Media Group 